Revista Eletrônica de Direito Processual - REDP.

Rio de Janeiro. Ano 10. Volume 17. Número 2. Julho a Dezembro de 2016

Periódico Semestral da Pós-Graduação Stricto Sensu em Direito Processual da UERJ

Patrono: José Carlos Barbosa Moreira. ISSN 1982-7636. pp. 298-319

www.redp.uerj.br

\title{
INQUÉRITO CIVIL, CONTRADITÓRIO E IMPROBIDADE ADMINISTRATIVA: \\ UM DIAGNÓSTICO CRÍTICO DOS PRECEDENTES DAS CORTES SUPREMAS \\ BRASILEIRAS ${ }^{1}$
}

CIVIL INVESTIGATION PROCEDURE, CONTRADICTORY AND

ADMINISTRATIVE MISCONDUCT: A CRITICAL DIAGNOSIS OF THE

BRAZILIAN SUPREME COURTS PRECEDENTS

Hermes Zaneti Júnior

Pós-Doutor em Direito pela Università degli Studi di Torino. Doutor em Direito pela Universidade Federal do Rio Grande do Sul. Doutor em Direito pela Università degli Studi di Roma Tré. Mestre em Direito pela Universidade Federal do Rio Grande do Sul, Graduado em Ciências Jurídicas e Sociais pela Universidade do Vale do Rio dos Sinos. Professor da Graduação e Pós Graduação (Mestrado) da Universidade Federal do Espírito Santo (UFES). Promotor de Justiça no Estado do Espírito Santo.

hermeszanetijr@gmail.com

Gustavo Silva Alves

Mestrando em Direito Processual Civil pela Universidade Federal do Espírito Santo (UFES). Graduado em Direito pela Universidade Federal do Espírito Santo (UFES). Participante do Grupo de Pesquisa "Fundamentos do Processo Civil Contemporâneo" (FPCC) da Universidade Federal do Espírito Santo, liderado pelos professores Antônio Gidi (University of Syracuse) e Hermes Zaneti Jr. (UFES). Advogado. gugalves2003@gmail.com

RESUMO: O presente trabalho propõe-se a realizar uma análise dos precedentes do STF e STF sobre a temática do Inquérito Civil. A partir disso, verifica-se a necessidade de incidência de uma progressiva abertura procedimental para um efetivo contraditório durante todo o andamento do inquérito civil (IC), tomando como parâmetro a crescente processualização dos procedimentos na ordem constitucional brasileira.

\footnotetext{
${ }^{1}$ Artigo recebido em 16/08/2016 e aprovado em 29/09/2016.
} 
Revista Eletrônica de Direito Processual - REDP.

Rio de Janeiro. Ano 10. Volume 17. Número 2. Julho a Dezembro de 2016

Periódico Semestral da Pós-Graduação Stricto Sensu em Direito Processual da UERJ

Patrono: José Carlos Barbosa Moreira. ISSN 1982-7636. pp. 298-319

www.redp.uerj.br

PALAVRAS-CHAVE: Inquérito Civil; Improbidade Administrativa; Precedentes;

Contraditório; Processualização dos procedimentos.

ABSTRACT: This paper proposes to analyze the precedents of the Brazilians Supremes Courts - STF and STJ - on the subject of Brazilian Civil Investigation Procedure. From this perspective, it intend to demonstrate the need of existence of a progressive procedimental opening for an effective participation of the investigated throughout the whole course of the investigation (right to be head), taking as parameter the need for a "constitutionalization" of administrative procedures in the Brazilian legal system.

KEYWORDS: Brazilian Civil Investigation Procedure; Administrative Misconduct; Precedents; "Constitutionalization" of Administrative Procedures.

SUMÁRIO: 1. Introdução. 2. O Inquérito Civil nas Ações de Improbidade Administrativa: Aspectos Gerais do Instrumento Investigativo. 3. Uma análise crítica dos precedentes dos Tribunais Superiores sobre a temática. 3.1. O modelo de precedentes normativos formalmente vinculantes previsto no CPC/15. Importância da análise das decisões das Cortes Supremas. 3.2. A identificação dos pontos controvertidos nas rationes decidendi dos precedentes do STF e STJ. 3.3. Da (in)existência do contraditório no Inquérito Civil: Efetividade da Investigação (Tutela dos Direitos) v. Garantias dos Investigados. 3.3.1. As Repercussões do Contraditório no Inquérito Civil: Solução Consensual dos Litígios e o Princípio da Efetividade. 4. Conclusões. Referências Bibliográficas.

\section{Introdução}

O presente trabalho propõe-se a analisar os precedentes do STF e STJ referentes à matéria do Inquérito Civil (IC) com o escopo de demonstrar a necessidade de que o IC seja considerado como um procedimento formal e progressivamente respeite o contraditório.

Para isso, em um primeiro momento, delimitam-se alguns aspectos gerais do instrumento, como conceito, legitimidade e objeto, sempre com o enfoque voltado para as investigações de atos de Improbidade Administrativa, previstos na Lei 8.429/92. Posteriormente trabalha-se de forma breve o modelo de precedentes normativos 
Revista Eletrônica de Direito Processual - REDP.

Rio de Janeiro. Ano 10. Volume 17. Número 2. Julho a Dezembro de 2016

Periódico Semestral da Pós-Graduação Stricto Sensu em Direito Processual da UERJ

Patrono: José Carlos Barbosa Moreira. ISSN 1982-7636. pp. 298-319

www.redp.uerj.br

formalmente vinculantes para compreender a importância de uma adequada análise dos julgados das Cortes Supremas.

Por fim, apresentam-se diversos trechos das rationes decidendi de diversos julgados do STF e STJ, sendo feitos, posteriormente, comentários e críticas ao atual posicionamento adotado pelas referidas Cortes.

\section{O Inquérito Civil nas Ações de Improbidade Administrativa: Aspectos Gerais do Instrumento Investigativo.}

Com o intuito de realizada uma adequada análise de qualquer instituto jurídico é imprescindível à fixação de um conceito acerca deste. Assim, em relação ao objeto de estudo deste trabalho, pode-se dizer que, o Inquérito Civil é um procedimento administrativo nãojurisdicional, do qual é titular exclusivo o Ministério Público ${ }^{2}$. Realizado préprocessualmente, constitui meio idôneo destinado a coligir material probatório, elementos aptos à formação da convicção do órgão ministerial em sua atuação em juízo e dados para efetivação de soluções extrajudiciais como a mediação, a conciliação, a negociação direta e a transação.

Tal instrumento está previsto constitucionalmente, de forma geral, no artigo 129, inciso III da CF/88, existindo ainda previsão em legislação infraconstitucional, por exemplo, no artigo $8^{\circ}$, parágrafo $1^{\circ}$ da Lei $n^{\circ} 7.347 / 85$ (Ação Civil Pública), artigo $6^{\circ}$ da Lei $n^{\circ}$ 7.853/1989 (Proteção às pessoas de deficiência), arts. 223 c/c 201, V da Lei nº 8.069/90 (Estatuto da Criança e do Adolescente), os art. 90 da Lei 8.078/90 (Código de Defesa do Consumidor), art. 25, IV, da Lei 8.625/93 (LONMP) $7^{\circ}$, I da LC 75/93 (LOMPU) entre outros. A regulamentação específica do IC no âmbito do Ministério Público Brasileiro está prevista na Resolução nº 23, de 17 de setembro de 2007, do Conselho Nacional do Ministério Público (CNMP).

Sobressai, ainda, o último objetivo apresentado, em relação à solução extrajudicial e consensual dos conflitos. Por sua previsão como norma fundamental, no artigo $3^{\circ}$, parágrafos

\footnotetext{
${ }^{2}$ Como aponta Marcelo Abelha: "O inquérito Civil constitui um instrumento (posto que não tem um fim em si mesmo) não jurisdicional, de índole administrativa, identificado como sendo um procedimento exclusivamente à disposição do parquet, voltado à coleta de elementos para formação de convicção deste órgão com vistas à eventual propositura de ação civil" (ABELHA, Marcelo. Ação Civil Pública e Meio Ambiente. São Paulo: Forense Universitária, 2003, p. 92).
} 
Revista Eletrônica de Direito Processual - REDP.

Rio de Janeiro. Ano 10. Volume 17. Número 2. Julho a Dezembro de 2016

Periódico Semestral da Pós-Graduação Stricto Sensu em Direito Processual da UERJ

Patrono: José Carlos Barbosa Moreira. ISSN 1982-7636. pp. 298-319

www.redp.uerj.br

$2^{\circ}$ e $3^{\circ}$ do $\mathrm{CPC} / 15^{3}$, esta deve ser fomentada por todos os atores processuais, entre eles, o

Ministério Público, o qual possui a sua disposição mecanismo para soluções consensuais de extrema relevância, o Termo de Ajustamento de Conduta (TAC) ${ }^{4}$, previsto no artigo $5^{\circ}$, parágrafo $6^{\circ}$ da Lei $7.347 / 85$.

Nessa toada, como dito, o Inquérito Civil é instrumento de atuação exclusiva do Ministério Público ${ }^{5}$, sendo importantíssimo destacar que o papel do Parquet, no atual estágio em que o ordenamento jurídico brasileiro se encontra, deve estar voltado à garantia dos direitos fundamentais e à defesa da ordem jurídica e do regime democrático ${ }^{6}$. Entre esses e outros motivos, afirma-se que essa função resolutiva deixou de ser subsidiária, passando a assumir, agora, papel cada vez mais central em sua atuação, inclusive nos Inquéritos Civis. Assim, o MP deve prestigiar, sempre que possível, os mecanismos da justiça multiportas previstos no $\mathrm{CPC} / 15^{7}$, como meios alternativos de possibilitar uma adequada e satisfativa tutela dos direitos.

Quanto ao objeto do Inquérito Civil, este será o mais amplo possível, a apuração de elementos e dados probatórios incide sobre quaisquer fatos que possam levar à propositura de ação da qual o Ministério Público é titular, ligando-se assim, a tutela de direitos

\footnotetext{
${ }^{3}$ MARINONI, Luiz Guilherme; ARENHART, Sérgio Cruz; MITIDIERO, Daniel. Novo Código de Processo Civil Comentado. São Paulo: Revista dos Tribunais, 2015, p. 96-97; DIDIER JR., Fredie. Comentários ao artigo $3^{\circ}$ do CPC/15. In: CABRAL, Antônio do Passo; CRAMER, Ronaldo. Comentários ao Novo Código de Processo Civil. São Paulo: Forense, 2015, p. 5-10.

${ }^{4}$ Conferir sobre o tema: CABRAL, Antônio do Passo. As convenções processuais e o termo de ajustamento de conduta. In: ZANETI JR., Hermes. Repercussões do Novo CPC: Processo Coletivo. Salvador. Juspodivm, 2016, p. 319-332; TESHEINER, José Maria; PEZZE, Sabrina. Inquérito Civil e Termo de Ajustamento de Conduta. In: Revista de Direito Administrativo, Rio de Janeiro, v. 263, mai/ago. 2013, p. 67-94.

${ }^{5}$ No que diz respeito à titularidade exclusiva do Ministério Público, vale destacar, que outros entes legitimados à propor uma ação civil pública podem se valer ação de produção antecipada de provas, prevista no artigo 381 do CPC/15 e que foi ampliada e alterada no novo diploma processual brasileiro. Sobre o tema conferir: DIDIER JR., Fredie; ZANETI JR., Hermes. Curso de Direito Processual Civil. Processo Coletivo. 10 a ed. v. 4. Salvador: Juspodivm, 2016, p. 252-256. Já vinha apontando nesse sentido, Daniel Assumpção, ao relacionar o Inquérito Civil à ação cautelar preparatória de provas: NEVES, Daniel Amorim Assumpção. O inquérito civil como uma cautelar preparatória probatória sui generis. In: MAZZEI. Rodrigo; NOLASCO, Rita Dias (coord). Processo Civil Coletivo. São Paulo: Quatier Latin, 2005, p. 215-245.

${ }^{6}$ Ver amplamente sobre o papel do Ministério Público no Estado Democrático Constitucional de Direito: ZANETI JR., Hermes. Comentários aos artigos 176 a 181 do CPC/15. In: STRECK, Lênio; NUNES, Dierle; CUNHA, Leonardo Carneiro da. Comentários ao Código de Processo Civil. São Paulo: Saraiva, 2016, p. 260282.

${ }^{7}$ Existe na Inglaterra de mecanismo análogo ao Inquérito Civil, as chamadas pre-actions protocols que tem como um dos objetivos principais "promover e estimular o acordo, evitando-se, assim, um processo, ou pelo menos abrir caminho para um litígio focado e mais eficiente, caso este não posso ser evitado" (ANDREWS, Neil. O Moderno Processo Civil. Formas judiciais e alternativas de resolução de conflitos na Inglaterra. Trad.: WAMBIER, Teresa Arruda Alvim. $2^{\text {a }}$ ed. São Paulo: Revista dos Tribunais, 2012, p. 205). Como citado. o CPC adotou o procedimento probatório antecedente com esta finalidade no art. 381, II, que trata da produção antecipada de provas para fins de viabilizar a autocomposição ou outro meio adequado de solução de conflitos.
} 
Revista Eletrônica de Direito Processual - REDP.

Rio de Janeiro. Ano 10. Volume 17. Número 2. Julho a Dezembro de 2016

Periódico Semestral da Pós-Graduação Stricto Sensu em Direito Processual da UERJ

Patrono: José Carlos Barbosa Moreira. ISSN 1982-7636. pp. 298-319

www.redp.uerj.br

individuais - de espectro social e indisponível - ou ainda sobre direitos coletivos em sentido

lato (difusos, coletivos e individuais homogêneos). Justamente esta é a normativa que se encontra no artigo $1^{\circ}$ da Resolução ${ }^{\circ}$ 23/2007 do CNMP ${ }^{8}$.

Relativamente à possibilidade de instauração do procedimento investigativo para apuração de fatos que possam resultar em ações de improbidade administrativa, acentua-se, em que pese à falta de previsão na Lei $\mathrm{n}^{\circ} 8.429 / 92$, os precedentes $^{9}$ e a doutrina ${ }^{10}$ são uníssonos quanto à viabilidade da utilização do IC nesses casos.

A referida lei não deve ser analisada isoladamente, há de se fazer uma interpretação constitucionalmente adequada, a partir do artigo 129 , inciso III da $\mathrm{CF} / 88$, que dita estar entre as funções institucionais do Ministério Público "promover o inquérito civil [...], para a proteção do patrimônio público e social, do meio ambiente e de outros interesses difusos e coletivos".

Assim, quando se fala em probidade administrativa, deve-se ter em mente, exatamente, à tutela do patrimônio público, mais especificadamente, da moralidade administrativa a que faz referência o artigo 37 , parágrafo $4^{\circ}$ da $\mathrm{CF} / 88^{11}$. Não há justificativa plausível para proibir a utilização do Inquérito Civil nas investigações referentes à improbidade administrativa, isso porque se está permitindo a adequada tutela de um direito difuso, com enorme espectro social, como o é, o direito a uma Administração proba ${ }^{12}$. Todos os mecanismos procedimentais disponíveis ao Ministério Público, entre eles o Inquérito

\footnotetext{
${ }^{8}$ Artigo $1^{\circ}$ : O inquérito civil, de natureza unilateral e facultativa, será instaurado para apurar fato que possa autorizar a tutela dos interesses ou direitos a cargo do Ministério Público nos termos da legislação aplicável, servindo como preparação para o exercício das atribuições inerentes às suas funções institucionais.

${ }^{9}$ STJ, AgRg no AREsp 113436/SP, Rel. Min. Benedito Gonçalves, Primeira Turma, DJe 18/05/2012; STJ, REsp 401.472/RO, Rel. Min. Herman Benjamin, Segunda Turma, DJe 27/04/2011; STJ, REsp 644994/MG, Rel. Min. João Otávio de Noronha, Segunda Turma, DJ 21/03/2005 p. 336.

10 "Pelo que se percebe da disciplina constitucional e legal, a ação civil pública e inquérito civil são instrumentos que se relacionam com grande intimidade, servindo este último à identificação da hipótese legitimadora da atuação do Parquet [...] é nessa perspectiva que deve ser interpretado o artigo 22 da Lei 8.429/92 (Para apurar qualquer ilícito previsto nesta lei, o Ministério Público, de ofício, a requerimento de autoridade administrativa ou mediante representação formulada de acordo com o disposto no art. 14, poderá requisitar a instauração de inquérito policial ou procedimento administrativo), regra concebida pelo legislador apenas de modo a facilitar a apuração da improbidade, nunca para negar ao Ministério Público a possibilidade de instauração do inquérito. Conclusão contrária não se afinaria ao texto constitucional" (GARCIA, Emerson; ALVES, Rogério Pacheco. Improbidade Administrativa. $6^{\text {a }}$ ed. Rio de Janeiro: Lumen Juris, 2011, p. 656).

${ }^{11}$ FIGUEIREDO, Marcelo. Probidade Administrativa. $5^{\text {a }}$ ed. atualizada e ampliada. São Paulo: Malheiros, 2005, p. 41-43.

${ }^{12}$ LOUREIRO, Valtair Lemos. Microssistema processual coletivo e tutela do patrimônio público. Curitiba: Juruá, 2015, p. 15-22 e p. 59-60.
} 
Revista Eletrônica de Direito Processual - REDP.

Rio de Janeiro. Ano 10. Volume 17. Número 2. Julho a Dezembro de 2016

Periódico Semestral da Pós-Graduação Stricto Sensu em Direito Processual da UERJ

Patrono: José Carlos Barbosa Moreira. ISSN 1982-7636. pp. 298-319

www.redp.uerj.br

Civil, ainda que não prescritos na Lei ${ }^{\circ}$ 8.429/92, podem e devem ser envidados pelo

Parquet, na perquirição de suas funções institucionais.

A partir das anotações realizadas sobre algumas características gerais do Inquérito

Civil e de sua aplicabilidade a fatos referentes à improbidade administrativa, analisar-se-á a seguir os precedentes dos Tribunais Superiores no que diz respeito a dois importantes aspectos da utilização do IC na apuração de atos de improbidade: a (in)existência ou (des)necessidade do contraditório e a processualização do procedimento.

\section{Uma análise crítica dos precedentes dos Tribunais Superiores sobre a temática.}

\subsection{O modelo de precedentes normativos formalmente vinculantes previsto no CPC/15. Importância da análise das decisões do STF e STJ.}

Em um primeiro momento é necessário apontar que o Código de Processo Civil de 2015 adotou um modelo de precedentes normativos formalmente vinculantes e seu núcleo normativo está previsto nos artigos 489, parágrafo $1^{\circ}$, inciso IV e V, 926 e 927 do CPC $/ 15^{13}$. Assim, o artigo 927 do CPC/15 estabelece um rol de precedentes formalmente vinculantes, os quais devem ser observados e levados em consideração, a partir de uma fundamentação adequada e analítica, para que sejam devidamente aplicados ou afastados/superados.

Essa observação é feita a partir da identificação dos fundamentos determinantes do precedente, a chamada ratio decidendi, consistente na solução fático-jurídica aplicada no julgado. Dessa forma, caso os fundamentos determinantes identificados no precedente se adequem ao caso análogo levado a juízo, o precedente deve ser aplicado (artigo 489, par. $1^{\circ}$, inciso V c/c 927 do CPC/15). Por outro lado, tratando-se de situação diversa, o julgador deverá realizar a distinção entre o precedente e o caso sob análise (artigo 489, par. $1^{\circ}$, inciso VI do CPC/15) ${ }^{14}$.

\footnotetext{
13 Ver amplamente sobre o tema: ZANETI JR., Hermes. O valor vinculante dos precedentes: teoria dos precedentes normativos formalmente vinculantes [2015]. $2^{\mathrm{a}}$ ed. Salvador: JusPodivm, 2016; MARINONI, Luiz Guilherme. Precedentes Obrigatórios. 4a ed. São Paulo: Revista dos Tribunais, 2015; MITIDIERO, Daniel. Precedentes: da persuasão à vinculação. São Paulo: Revista dos Tribunais, 2016.

14 “Assim, incumbe ao julgador do caso-atual demonstrar '[...] fundamentadamente se tratar de situação particularizada por hipótese fática distinta ou questão jurídica não examinada, a impor solução jurídica diversa". A questão é de fundamental importância, por exemplo, no julgamento dos casos repetitivos, nos quais o CPC determina a verificação pelo tribunal de todos os argumentos favoráveis e contrários à tese jurídica
} 
Revista Eletrônica de Direito Processual - REDP.

Rio de Janeiro. Ano 10. Volume 17. Número 2. Julho a Dezembro de 2016

Periódico Semestral da Pós-Graduação Stricto Sensu em Direito Processual da UERJ

Patrono: José Carlos Barbosa Moreira. ISSN 1982-7636. pp. 298-319

www.redp.uerj.br

A ideia básica é que os juízes e tribunais decidam casos análogos ou similares da mesma forma - treat like cases alike - com o intuito de garantir maior racionalidade e unidade à ordem jurídica, a partir da integridade, coerência e consistência, previstas no artigo 926 do $\mathrm{CPC} / 15$.

Primordial relevar, nesse momento, que essa sistemática dos precedentes normativos formalmente vinculantes alterará substancialmente a forma como os operadores compreendem e interpretam o direito. A partir desse momento, os precedentes configuramse como must-sources, como fontes formais do direito, de mesmo grau hierárquico e vinculativo que os textos legais ${ }^{15}$.

Nesse diapasão, as Cortes Supremas - STF e STJ - ganham ainda mais destaque no ordenamento jurídico $^{16}$, por serem cortes de vértice, a cada uma delas exige-se a função de dar unidade à interpretação do direito constitucional, no caso do STF, e do direito infraconstitucional federal, em relação ao STJ. Além disso, tais Cortes possuem um ônus argumentativo para afastar ou superar a aplicação de um antigo precedente, por estarem vinculadas aos seus próprios precedentes ${ }^{17}$.

Estabelecidas essas premissas, salienta-se novamente a relevância de uma análise adequada e crítica dos precedentes formados no STF e STJ, tanto pelos juristas práticos (aplicadores), quanto pelos acadêmicos do direito (doutrina). Como dito, é uma mudança de perspectiva que irá incidir sobre todos os membros da comunidade jurídica. Apresentam-se

discutida (art. $984, \S 2^{\circ}$, e art. $1.038, \S 3^{\circ}$ )'." (ZANETI JR., Hermes. $O$ valor vinculante dos precedentes, cit., p. 355).

${ }^{15}$ Tratando sobre o grau de vinculatividade e autoridade dos precedentes e das outras fontes do direito, cf.: AARNIO, Aulis. The rational as reasonable. A Treatise on Legal Justification. Dordrecht/Holland: D. Reidel Publishing Company, 1986, 78-94; PECZENIK, Aleksander. On Law and Reason. Netherlands: Springer, 2009, p. 262-281.

16 "O Supremo Tribunal Federal e o Superior Tribunal de Justiça, como cortes responsáveis por dar à última palavra a respeito da interpretação da Constituição e da Legislação infraconstitucional federal na ordem jurídica brasileira, devem ser pensados como Cortes Supremas, a fim de que se possa reconstruí-los em termos conceituais, estruturais, funcionais e eficaciais a partir de um quadro teórico capaz de fornecer soluções coerentes aos problemas ligados à interpretação judicial no Estado Constitucional. Nessa linha, o Supremo Tribunal Federal e o Superior Tribunal de Justiça devem ser pensados, como cortes de interpretação e não como cortes de controle, como cortes de precedentes e não como cortes de jurisprudência, tendo autogoverno e sendo dotados de meios idôneos para consecução da tutela do direito em uma dimensão geral de forma isonômica e segura (MITIDIERO, Daniel. Cortes Superiores e Cortes Supremas. Do Controle à Interpretação, da Jurisprudência ao Precedente. $2^{\mathrm{a}}$ ed. revista, atualizada e ampliada. São Paulo: Revista dos Tribunais, 2015, p. 81). No mesmo sentido: TARUFFO, Michele. Il Vertice Ambiguo: Saggi sulla Cassazione Civile. Bolgna: Il Mulino, 1991; TARUFFO, Michele. Precedente e giurisprudenza. Napoli: Editoriale Scientifica, 2007.

${ }^{17}$ ZANETI JR., Hermes. Comentários ao artigo 926 do CPC/15. In: CABRAL, Antônio do Passo; CRAMER, Ronaldo. Comentários ao Novo Código de Processo Civil. São Paulo: Forense, 2015, p. 1309. 
Revista Eletrônica de Direito Processual - REDP.

Rio de Janeiro. Ano 10. Volume 17. Número 2. Julho a Dezembro de 2016

Periódico Semestral da Pós-Graduação Stricto Sensu em Direito Processual da UERJ

Patrono: José Carlos Barbosa Moreira. ISSN 1982-7636. pp. 298-319

www.redp.uerj.br

na sequência, dois pontos controvertidos identificados nas rationes decidendi dos precedentes a respeito do IC.

\subsection{A identificação dos pontos controvertidos nas rationes decidendi dos precedentes do STF e STJ a respeito do Inquérito Civil.}

A partir da pesquisa e análise das rationes decidendi de diversos julgados do STF e STJ, percebeu-se que os Tribunais Superiores têm adotado posicionamentos polêmicos sobre a temática do Inquérito Civil, considerando-o como um procedimento inquisitivo e informal, no qual inexiste a presença e necessidade de contraditório.

Colaciona-se a seguir, trechos dos votos que confirmam a afirmação realizada acima: "[...] A jurisprudência do Supremo Tribunal Federal firmou-se no sentido de que as garantias constitucionais da ampla defesa e do contraditório não são aplicáveis na fase de inquérito civil, pois este tem natureza administrativa, de caráter pré-processual, que se destina à colheita de informações para a propositura da ação civil pública, não havendo, portanto, que se falar em réu ou acusado, nessa fase investigativa" (STF, RE 481.955, Rel Min. Carmen Lúcia, Primeira Turma, julgado em 10.5.2011) ${ }^{18}$.

"[...] Correto o entendimento do Parquet, pois o inquérito civil público tem natureza inquisitorial, por ser peça informativa. $\mathrm{O}$ contraditório e a ampla defesa devem espaço no decorrer da instrução criminal, e não âmbito de procedimento administrativo meramente informativo" (STJ, HC 175.596/MG, Rel. Ministra LAURITA VAZ, QUINTA TURMA, julgado em 27/11/2012, p. 12, DJe 05/12/2012).

\footnotetext{
${ }^{18}$ Foi citado nesse julgado, o seguintes precedente do STF: Inq 897 AgR, Relator Min. FRANCISCO REZEK, Tribunal Pleno, julgado em 23/11/1994, DJ 24-03-1995.
} 
Revista Eletrônica de Direito Processual - REDP.

Rio de Janeiro. Ano 10. Volume 17. Número 2. Julho a Dezembro de 2016

Periódico Semestral da Pós-Graduação Stricto Sensu em Direito Processual da UERJ

Patrono: José Carlos Barbosa Moreira. ISSN 1982-7636. pp. 298-319 www.redp.uerj.br

“[...] Ademais, ainda que se enfrente o mérito da questão, tem-se que, embora existam diversos precedentes nesta Corte Superior afirmando a desnecessidade de defesa no âmbito do inquérito civil, tendo em vista sua característica informativa e inquisitória (v.g: RMS 21.038MG, Primeira Turma, Rel. Min. LUIZ FUX, DJe de 01/06/2009), nenhum deles dispensa a observância dos princípios do contraditório e da ampla defesa no âmbito judicial. Efetivamente, se utilizado o inquérito civil como base probatória para instruir ação civil pública, deve, na esfera judicial, ser garantido o direito de defesa, eventualmente não observado na fase inquisitorial" (STJ, AgRg no REsp 659.571/RS, Rel. Ministro RAUL ARAÚJO, QUARTA TURMA, julgado em 04/02/2014, DJe 17/02/2014).

"[...] provas colhidas no inquérito têm valor probatório relativo, porque colhidas sem a observância do contraditório, mas só devem ser afastadas quando há contraprova de hierarquia superior, ou seja, produzida sob a vigilância do contraditório" (STJ, REsp n. 476.660MG, Rel. Ministra Eliana Calmon, DJ de 4.8.2003)."19

"PROCESSO CIVIL - MANDADO DE SEGURANÇA PARA TRANCAR AÇÃO CIVIL PÚBLICA, POR ATO DE IMPROBIDADE. 1. Carência de ação por falta de interesse. 2. No curso da ação civil será produzida a ampla defesa e observado o contraditório. 3. O inquérito civil que pode ou não anteceder a ação civil é informal e unilateral, porque se destina a recolher provas, tão-somente. 4. Recurso ordinário improvido" (STJ, RMS 11537/MA, Ministra ELIANA CALMON, T2 - SEGUNDA TURMA, ,DJe 29/10/2001, p. 190)

\footnotetext{
${ }^{19}$ Vale destacar que esse precedente da Ministra Eliana Calmon é citado em diversas outras decisões sobre a temática, vale conferir: STJ, AgRg no AREsp 572.859/RJ, Rel. Ministro HUMBERTO MARTINS, SEGUNDA TURMA, julgado em 18/12/2014, DJe 03/02/2015; STJ, REsp 849841/MG, Rel. Ministra ELIANA CALMON, T2 - SEGUNDA TURMA, julgado em 28/08/2007, DJ 11/09/2007, p. 216.
} 
Revista Eletrônica de Direito Processual - REDP.

Rio de Janeiro. Ano 10. Volume 17. Número 2. Julho a Dezembro de 2016

Periódico Semestral da Pós-Graduação Stricto Sensu em Direito Processual da UERJ

Patrono: José Carlos Barbosa Moreira. ISSN 1982-7636. pp. 298-319

www.redp.uerj.br

Com a devida vênia, não se coaduna, no presente trabalho, com as ideias defendidas nos julgados apresentados, por essa razão, tentar-se-á, demonstrar a seguir, porque $a$ compreensão das Cortes Supremas a respeito do Inquérito Civil, como um procedimento puramente inquisitivo, informal e sem contraditório, não pode prosperar no atual estágio de evolução da ordem jurídica brasileira.

O inquérito civil atualmente é procedimento formal, tendencialmente inquisitivo, que deve preservar o direito - sempre que possível - aos investigados e representantes (destinatários do ato final) consistente na tríplice opção: a) ajuizamento da ação; b) compromisso de ajustamento de conduta às exigências do ordenamento jurídico; ou, c) arquivamento. Preserva-se assim, o direito de influenciar na tomada de decisão, propiciando a progressiva processualização ${ }^{20}$ através da garantia do contraditório.

\subsection{Da (in)existência ou (des)necessidade do contraditório no Inquérito Civil:} Efetividade da Investigação (Tutela dos Direitos) v. Garantias dos Investigados.

Primeiramente, deve ser destacado que grande parte da doutrina sempre defendeu a desnecessidade de contraditório em sede de Inquérito Civil, pelo fato de que, o procedimento não resulta em nenhuma sanção aos investigados, pois não altera ou infringe a esfera jurídica do cidadão, e por ser totalmente dispensável para o ajuizamento de possível ação pelo Ministério Público ${ }^{21}$.

Além disso, como se constatou nos precedentes, afirma-se não ser necessária à aplicação do princípio do contraditório, pois, as provas serão reproduzidas em sede judicial,

\footnotetext{
20 A processualização dos procedimentos é uma tendência contemporânea nos Estados Democráticos de Direito, ver amplamente: DANTAS, Miguel Calmon. O Direito Fundamental à Processualização: Fundamento para uma Teoria Geral do Processo. In: DIDIER Jr., Fredie; JORDÃO, Eduardo Ferreira (coord.). Teoria Geral do Processo: panorama doutrinário mundial. Salvador: Juspodivm, 2008.

21 “Ora, como procedimento administrativo, o inquérito civil não aplica nenhuma sanção, razão pela qual não há acusado; muito menos extingue, modifica ou cria direito, já que não se deduz, em seu objeto, nenhuma pretensão de direito material, inexistindo, portanto, litigantes. Resumindo, o inquérito civil não altera a esfera jurídica do cidadão. A sua única finalidade, já dissemos, é a de arregimentar provas para a formação da opinião jurídica do membro do Ministério Público, a fim de embasar a sua atuação institucional [...] esse instituto jurídico está fora da hipótese de incidência do dispositivo constitucional que cuida do contraditório e da ampla defesa" (QUEIROZ, Ronaldo Pinheiro de. A eficácia probatória do inquérito civil no processo judicial de combate à corrupção. In: SALGADO, Daniel de Resende; QUEIROZ, Ronaldo Pinheiro de. A Prova no Enfrentamento à Macrocriminalidade. Salvador: Juspodivm, 2015, p. 423-425). No mesmo sentido, negando a incidência do contraditório em sede de IC: MAZZILI, Hugo Nigro. Inquérito Civil e Poder Investigatório do MP In: MILARÉ, Édis (coord). A Ação Cvil Pública após 20 anos: efetividade e desafios. São Paulo: Revista dos Tribunais, 2005, p. 233.
} 
Revista Eletrônica de Direito Processual - REDP.

Rio de Janeiro. Ano 10. Volume 17. Número 2. Julho a Dezembro de 2016

Periódico Semestral da Pós-Graduação Stricto Sensu em Direito Processual da UERJ

Patrono: José Carlos Barbosa Moreira. ISSN 1982-7636. pp. 298-319

www.redp.uerj.br

logo, o possível réu poderia exercer o contraditório em juízo, durante o processamento de ação civil ajuizada pelo Parquet. Assim, por não configurar qualquer prejuízo ao investigado dispensa-se o contraditório no IC.

Entretanto, a situação é um pouco mais complexa, por duas razões: a) a necessidade de que o IC preste tutela adequada aos direitos; b) a necessidade de que sejam oferecidas garantias mínimas aos investigados para poder influenciar na tríplice opção do Parquet.

O direito deve sempre primar em uma sociedade democrática pela transparência e pelo acesso à informação. A imprensa é uma poderosa arma de formação cultural e política da esfera da sociedade civil, necessária e imprescindível em qualquer democracia. Sabe-se, contudo, que no Brasil e alhures, a mídia possui grande influência, a mera instauração de um Inquérito Civil pode resultar em notícias que acabem indiretamente atingindo a esfera jurídica do investigado. Possível resultado disso é a grande repressão e condenação social que ele pode vir a sofrer, pelo próprio desconhecimento da população sobre os trâmites e termos referentes ao direito ${ }^{22}$.

Tal fato ganha relevo, no que diz respeito aos cidadãos que são investigados, em sede de IC, por atos de improbidade. Isso porque, como se viu, nessas situações tutela-se o patrimônio público, defendem-se direitos que têm grande espectro social, logo, é da natureza dessas ações despertar o interesse e indignação geral da população. Imagina-se assim, o quão pode ser prejudicial a imagem do investigado à instauração de um IC, por exemplo, contra um agente político, seja ele, um vereador, um prefeito ou o presidente da república.

Não se está negando aqui, a extrema importância que o instrumento investigativo do Ministério Público possui na atual conjuntura, quer se apontar contudo que, ao lado da adequada tutela do patrimônio público, da probidade administrativa estão às garantias Constitucionais dos investigados, atinentes a qualquer Estado Democrático de Direito ${ }^{23}$.

A proposta do presente trabalho é que o contraditório incida durante todo o andamento do Inquérito Civil ${ }^{24}$, desde que não ocorra um prejuízo para a tutela dos direitos.

\footnotetext{
${ }^{22}$ Sobre o tema, arremata Marcelo Abelha: "Mas o fato é que, se o IC importa nas consequências mencionadas sobre a esfera pessoal dos inquiridos, e paralelamente a participação é meio de se obter a verdade, ora, não há justificativa lógica, legal e legítima para que a mesma seja impedida ou mutilada. Nesses casos a só notícia de um inquérito [...] mexe com o que há de mais importante para esses sujeitos: a imagem, o moral e a reputação, que, em virtude da ausência de contraditório, ficam impossibilitados de fornecer seus elementos de convicção, enfim, suas razões" (ABELHA, Marcelo. Ação Civil Pública e Meio Ambiente, cit., p. 99).

${ }^{23}$ DIDIER JR., Fredie; ZANETI JR., Hermes. Curso de Direito Processual Civil. Processo Coletivo, p. 246.

${ }^{24}$ Também sobre a incidência do contraditório no IC, cf.: CAVACO, Bruno de Sá Barcelos. O inquérito civil como instrumento efetivo e resolutivo na tutela dos interesses transindividuais - desjudicialização,
} 
Revista Eletrônica de Direito Processual - REDP.

Rio de Janeiro. Ano 10. Volume 17. Número 2. Julho a Dezembro de 2016

Periódico Semestral da Pós-Graduação Stricto Sensu em Direito Processual da UERJ

Patrono: José Carlos Barbosa Moreira. ISSN 1982-7636. pp. 298-319

www.redp.uerj.br

Quer dizer, deverá sempre existir um equilíbrio entre o binômio: tutela dos direitos $v$. garantias dos investigados.

Quando se trata da tutela dos direitos, tem-se em mente que o procedimento investigativo deve ser efetivo na coleta de elementos e dados probatórios que permitam uma adequada análise por parte do órgão ministerial de qual medida irá tomar, mas não só, muitas vezes haverá necessidade de segredo (para evitar intervenções indevidas, influência sobre as testemunhas ou evasão da responsabilidade, a exemplo da dilapidação do patrimônio para evitar a reparação in pecunia) ou urgência (perecimento do direito ou risco de perecimento dos bens jurídicos tutelados) que justifique a diminuição do contraditório, ou, ainda, por qualquer razão não se poderá localizar o investigado para permitir sua manifestação. Por essas razões o IC é tendencialmente inquisitivo. A resolução consensual do conflito, ajuizamento de ação ou arquivamento do Inquérito devem ser decisões tomadas, sempre que possível, com a oitiva dos investigados, mas se essa oitiva prejudicar a tutela dos direitos o Ministério Público deverá proceder sem a observância desta formalidade, ficando o contraditório diferido para a esfera judicial.

A tutela dos direitos é o fim do direito processual. Dessa forma, não é possível que, as garantias constitucionais dos investigados prejudiquem a efetividade da investigação e a adequada tutela dos direitos. Até porque o espaço próprio para o contraditório e para o devido processo legal, com homenagem ao direito à ampla defesa será o eventual processo judicial.

Por outro lado, em um Estado Democrático de Direito, como o é, o Brasil, a existência de um contraditório efetivo deve ser a regra em qualquer esfera estatal, seja ela, jurisdicional ou administrativa ${ }^{25}$. Portanto, tomando como parâmetro essa visão cooperativa $^{26}$ e democrático-participativa ${ }^{27}$ existente na dialética jurídico-processual contemporânea, sempre que possível, há de ser oportunizada ao investigado uma efetiva

contraditório e participação. In: Revista de Processo, São Paulo, v. 40, n. 247, set. 2015, p. 325-333; CARVALHO, Ulisses Dias de Carvalho. Uma leitura constitucional do inquérito civil. In: Boletim Científico ESMPU, ano 13, n. 42-43, jan./dez. 2014, p. 374-377.

${ }^{25}$ GRINOVER, Ada Pellegrini. Inquérito Civil: Contraditório e "Prova Inequívoca" para Fins de Antecipação da Tutela. In: Revista Síntese: Direito Civil e Processual Civil, v. 12, n. 83, maio/jun. 2013, p. 117-118.

${ }^{26}$ Sobre o tema cf.: MITIDIERO, Daniel. Colaboração no Processo Civil. Pressupostos sociais, lógicos e éticos. $3^{\text {a }}$ ed. São Paulo: Revista dos Tribunais, 2015.

27 “O que se entende por democracia participativa tem relação de fechamento com o que foi dito até aqui: Se o projeto de democracia da Constituição realmente se identifica com um futuro Estado democrático e policrático, as instâncias de participação democrática deverão ser tantas quantas sejam possíveis, e os poderes institucionalizados deverão abrir seu procedimento às luzes desses outros centros decisórios da sociedade civil" (ZANETI JR., Hermes. A Constitucionalização do Processo. O modelo constitucional da justiça brasileira e as relações entre processo e Constituição. $2^{\mathrm{a}}$ ed. São Paulo: Atlas, 2014, p. 128). 
Revista Eletrônica de Direito Processual - REDP.

Rio de Janeiro. Ano 10. Volume 17. Número 2. Julho a Dezembro de 2016

Periódico Semestral da Pós-Graduação Stricto Sensu em Direito Processual da UERJ

Patrono: José Carlos Barbosa Moreira. ISSN 1982-7636. pp. 298-319

www.redp.uerj.br

participação $^{28}$ em contraditório ${ }^{29}$ no IC. À vista disso, o resultado frutífero da investigação

e a tutela do patrimônio público não podem ser pensados como antagônicos à participação

dos investigados, para além das garantias constitucionais aos investigados a própria tutela adequada depende desta oitiva.

Com a oitiva dos investigados no IC podemos obter uma série de vantagens para a tutela dos direitos: a) maior celeridade e efetividade, vez que a oitiva prévia facilita os meios de autocomposição e negociação direta, inclusive para o adimplemento espontâneo total ou parcial das obrigações; b) robustecimento do material probatório produzido no IC, com possibilidade de utilizar a prova produzida em contraditório no IC como prova contraditada, invertendo-se o ônus e o custo da prova a ser produzida em juízo, a exemplo da prova pericial, visto que o juiz poderá dispensar a sua produção quando a prova houver sido produzida em contraditório (art. 472, CPC/2015); c) racionalização das demandas do MP, visto que as informações prestadas em contraditório poderão justificar o arquivamento sem o ajuizamento da ação, com economia de tempo e custos para o sistema de justiça e para os investigados.

Dois exemplos práticos do item $c$ ) podem nos ajudar a perceber sua extensão e importância. Em um caso ocorrido no MPGO foi ajuizada ação de improbidade em face de um servidor do Tribunal de Constas do Estado por ter sido constatado o seu ingresso sem concurso público posteriormente à Constituição de 1988. Após o ajuizamento o réu compareceu aos autos e juntou uma decisão do STF, transitada em julgado, determinando

\footnotetext{
${ }^{28}$ Fala-se em um direito fundamental à organização e participação nos procedimentos, existe assim, como defende Peter Haberle, um status activus processualis, ver sobre o tema: SARLET, Ingo Wolfgang. A eficácia dos direitos fundamentais. $4^{\mathrm{a}}$ ed. Porto Alegre: Livraria do Advogado, 2004, p. 213-218; ALEXY, Robert. Teoría de los Derechos Fundamentales. Traducción de Ernerto Garzón Valdés. Madrid: Centro de Estudios Políticos y Constitucionales, 2001, p. 454-482. Além disso, importante ressalvar também que atualmente o principio da legalidade vem ganhando novos contornos, defende-se agora a existência de um princípio da constitucionalidade, ou seja, a ideia de controle normativo a partir de uma adequada conformação com a Constituição, com o chamado "bloco de constitucionalidade" (ZANETI JR., Hermes. A Legalidade na era das Necessidades de Tutela: Princípio da Constitucionalidade e Legalidade Ampla. In: Normas Fundamentais (Coleção Grandes Temas do Novo CPC). Salvador: Juspodivm, 2016, p. 175-196). A doutrina portuguesa denominou essa amplitude e mutação de princípio da juridicidade, nesse sentido: OTERO, Paulo. Legalidade e administração pública: o sentido da vinculação administrativa à juridicidade. Lisboa: Almedina, 2003.

${ }^{29}$ Atualmente o Princípio do Contraditório não é visto apenas em sua bilateralidade, não está ligado somente à ideia de ação e reação das partes, mas sim como um dever de debates e um poder de influência. Sobre tema vale conferir: CABRAL, Antônio do Passo. Il principio del contradditorio come diritto d'influeza e dovere di dibattito. In: Rivista di Diritto Processuale, anno LX, n. 2, aprile-giugno, 2005; NUNES, Dierle José Coelho. O Princípio do Contraditório: Uma Garantia de Influência e de Não Surpresa. In: DIDIER Jr., Fredie; JORDÃO, Eduardo Ferreira (coord.). Teoria Geral do Processo: panorama doutrinário mundial. Salvador: Juspodivm, 2008, p. 151-173.
} 
Revista Eletrônica de Direito Processual - REDP.

Rio de Janeiro. Ano 10. Volume 17. Número 2. Julho a Dezembro de 2016

Periódico Semestral da Pós-Graduação Stricto Sensu em Direito Processual da UERJ

Patrono: José Carlos Barbosa Moreira. ISSN 1982-7636. pp. 298-319

www.redp.uerj.br

sua reintegração, pois havia sido "cassado" por perseguições políticas ao tempo da ditadura militar, a ação foi julgada improcedente. Em um segundo caso, ocorrido no MPES o Ministério Público aferiu em procedimento administrativo a inexistência de dolo, ao chamar o investigado para discutir a questão do ressarcimento foi possível efetuar um compromisso de ajustamento de conduta. Em ambos os casos se percebe o quanto se torna relevante a oitiva do investigado para a atuação do Ministério Público de perfil resolutivo e constitucional.

Nesse sentido, destaca-se a excelente iniciativa do Ministério Público do Estado do Espírito Santo, o qual possui norma específica sobre o contraditório em sede de IC, no artigo 22 da Resolução no 006/2014 do CSMP/ES, que trata do procedimento de tramitação de autos extrajudiciais:

Art. 22. O presidente do inquérito civil ou do procedimento preparatório, em cumprimento ao princípio do contraditório, deverá ouvir, ao final, o(s) investigado(s), podendo o(s) mesmo(s) se fazer (em) acompanhar por advogado, facultada a apresentação de informações por escrito, no prazo máximo de 15 (quinze) dias.

$\S 1^{\circ}$ Não se aplica o disposto no caput, deste artigo, nas hipóteses seguintes:

I - quando haja dificuldade justificada em fazê-lo; II - quando em situações justificadas de urgência, e; III - quando, de qualquer modo, possa refletir prejuízo à eficácia da investigação; IV - quando já fora ouvido em outro procedimento investigatório sobre os fatos investigados, mediante a juntada da respectiva prova emprestada.

$\S 2^{\circ}$ Ao ser notificado, o investigado será cientificado dessa condição e da faculdade de se fazer acompanhar por advogado e de trazer os subsídios que entender necessários.

$\S 3^{\circ}$ A critério do presidente do inquérito civil, o momento da(s) oitiva(s) do(s) investigado(s) poderá ser antecipado.

$\S 4^{\circ}$ No caso do investigado ou seu advogado requerer diligências, o presidente apreciará a conveniência e a oportunidade da sua realização, arcando o(s) investigado(s) com eventuais despesas. 
Revista Eletrônica de Direito Processual - REDP.

Rio de Janeiro. Ano 10. Volume 17. Número 2. Julho a Dezembro de 2016

Periódico Semestral da Pós-Graduação Stricto Sensu em Direito Processual da UERJ

Patrono: José Carlos Barbosa Moreira. ISSN 1982-7636. pp. 298-319

www.redp.uerj.br

$\S 5^{\circ} \mathrm{E}$ facultado ao investigado, no curso do inquérito civil, requerer

pessoalmente ou por seu advogado, a juntada de documentos aos autos do procedimento, cujo deferimento dependerá da pertinência com o fato investigado.

Nesse diapasão, a própria natureza sancionatória dúplice da ação de improbidade administrativa (artigo 37, par. $4^{\circ}$ da CF/88 e artigo 12 da Lei $\mathrm{n}^{\circ}$ 8.429/92) comprova a utilidade da adequação do contraditório ao binômio, tutela dos direitos e garantias dos Investigados. Porquanto, existem sanções de natureza reparatória (ressarcimento ao erário), que visam à recomposição do patrimônio público ou o desfazimento de atos contrários à probidade administrativa e, sanções de natureza punitiva (suspensão dos direitos políticos, a perda da função pública, a indisponibilidade de bens, proibição de contratar com o Poder Público), que visam à aplicação de penas pessoais ao agente improbo ${ }^{30}$. Ao se permitir o exercício do contraditório prévio como garantia poder-se-á obter o resultado almejado para a tutela dos direitos até mesmo sem a necessidade do processo judicial ou reduzir o seu âmbito apenas a uma parcela das questões objeto do procedimento.

Assim, fica clara, novamente, a necessidade de harmonização entre o referido binômio que não se encontra em contradição, mas em relação de complementariedade, pois, se por um lado, deve existir uma adequada tutela do patrimônio público, que pode vir a cominar em ressarcimento ao erário, também, há que se considerar as possíveis sanções pessoais que o agente improbo pode sofrer, com o intuito de garantir sua participação em contraditório no IC.

A ausência de contraditório prévio, contudo, não pode ensejar, no estado atual do ordenamento jurídico, qualquer sanção ao órgão do Ministério Público ou qualquer nulidade ao procedimento do IC, visto que, como se viu o procedimento não exige o contraditório e este não é obrigatório para o ajuizamento da ação, apesar de ele ser um desdobramento do direito de participação garantido na Constituição.

A tese aqui defendida é a de que a processualização do IC favorece a tutela dos direitos, sustentar nesta quadra da história qualquer formalismo garantista quanto à

${ }^{30}$ FAZZIO JR., Waldo. Atos de Improbidade Administrativa: doutrina, legislação e jurisprudência. São Paulo: Atlas, 2007, p. 343-354. 
Revista Eletrônica de Direito Processual - REDP.

Rio de Janeiro. Ano 10. Volume 17. Número 2. Julho a Dezembro de 2016

Periódico Semestral da Pós-Graduação Stricto Sensu em Direito Processual da UERJ

Patrono: José Carlos Barbosa Moreira. ISSN 1982-7636. pp. 298-319

www.redp.uerj.br

obrigatoriedade do contraditório nos procedimentos administrativos de investigação seria contrário a esta finalidade e por isto incorreto do ponto de vista formal e material.

\subsubsection{As Repercussões do Contraditório no Inquérito Civil: Solução Consensual dos Litígios e Prestígio ao Princípio da Efetividade.}

Restou inegável, a importância do contraditório em sede de IC, trabalha-se agora, com os impactos positivos que essa compreensão acarretará ao sistema jurídico brasileiro.

Primeiramente, aponta-se para a ideia de que, possibilitando uma participação efetiva do investigado, são aumentadas substancialmente as chances de uma solução consensual dos litígios ${ }^{31}$.

Como dito, o Parquet e outros órgãos do Poder Público têm a sua disposição, instrumento conciliatório, o compromisso de ajustamento de conduta as exigências do ordenamento jurídico (TAC), previsto no artigo $5^{\circ}$, parágrafo $6^{\circ}$ da Lei $\mathrm{n}^{\circ} .7 .347 / 85$ e em outros regramentos $^{32}$. Por meio do TAC, não é possível a dispensa de satisfação ao direito lesado, mas se permite que seja regulada a maneira como será feita a efetiva reparação dos prejuízos causados pelo agente ${ }^{33}$.

Diante disso, ao término de um Inquérito Civil que teve participação em contraditório, torna-se muito maior a chance de que o investigado se reúna com o órgão ministerial e juntos, tentem encontrar uma adequada forma de reparação aos danos

\footnotetext{
${ }^{31}$ É exatamente essa perspectiva participativa e a possibilidade de conciliação que acentua a importância dos pre-actions protocols no direito inglês (ANDREWS, Neil. O Moderno Processo Civil, cit., p. 127-128). Nesse sentido está à disposição geral prevista nas "Orientações sobre a prática dos pre-actions protocols": "Where there is a relevant pre-action protocol, the parties should comply with that protocol before commencing proceedings. Where there is no relevant pre-action protocol, the parties should exchange correspondence and information to comply with the objectives in paragraph $3([\ldots]$ (c) try to settle the issues without proceedings; (d) consider a form of Alternative Dispute Resolution (ADR) to assist with settlement), bearing in mind that compliance should be proportionate".

${ }^{32}$ DIDIER JR., Fredie; ZANETI JR., Hermes. Curso de Direito Processual Civil. Processo Coletivo, cit., p. 309; TESHEINER, José Maria; PEZZE, Sabrina. Inquérito Civil e Termo de Ajustamento de Conduta, cit., p.79-80.

${ }^{33}$ Isso não quer dizer que o "espaço para negociação" seja pequeno. Como afirma Ana Luíza Nery: "o espaço transacional possível no compromisso de ajustamento de conduta não se refere a aspectos meramente formais do negócio [...] As partes poderão entabular, no compromisso, direitos e deveres para ambas, que lhe confiram caráter de máxima eficiência para os fins pretendidos pelos celebrantes. Assim, poderão ser previstas obrigações a serem cumpridas tanto pelo particular como pela entidade pública que celebra o ajustamento" (NERY, Ana Luíza de Andrade. Compromisso de Ajustamento de conduta. $2^{\mathrm{a}}$ ed. São Paulo: Revista dos Tribunais, 2012, p. 198).
} 
Revista Eletrônica de Direito Processual - REDP.

Rio de Janeiro. Ano 10. Volume 17. Número 2. Julho a Dezembro de 2016

Periódico Semestral da Pós-Graduação Stricto Sensu em Direito Processual da UERJ

Patrono: José Carlos Barbosa Moreira. ISSN 1982-7636. pp. 298-319

www.redp.uerj.br

produzidos por meio de um TAC, sem a necessidade do decurso de tempo que um possível processo judicial ocasionaria.

Agora, imaginando-se a situação contraria, será que o investigado se sentiria confortável em discutir a celebração de um TAC, a partir de dados e elementos probatórios que foram coletados exclusivamente pelo MP, sem sua participação? Acredita-se que a resposta seja negativa, dificilmente uma solução consensual se efetivaria, o inevitável processo se arrastaria por anos, e a tutela adequada, tempestiva e efetiva dos direitos (art. $4^{\circ}$ do $\mathrm{CPC} / 15)$ estaria comprometida. Além disso, a própria presença do contraditório no IC propicia uma maior credibilidade e força ao compromisso de ajustamento de conduta. Entre essas e outras justificativas, o Conselho Nacional do Ministério Público editou a Resolução CNMP n 118 , com o intuito de regular a autocomposição no âmbito do MP.

Nesse momento, ainda é importante salientar a vedação expressa à autocomposição no artigo 17, par. $1^{\circ}$ da Lei de Improbidade Administrativa. Vale destacar que tal dispositivo foi revogado pela Medida Provisória 703/2015, a qual infelizmente caducou em maio de 2016 por não ter sido votada pelo Congresso Nacional.

Entretanto, em que pese a revogação da Medida Provisória, a interpretação literal do dispositivo do art. $17, \S 1^{\circ}$. da LIA não deve mais prosperar, pois, não se coaduna com o estado atual do microssistema de combate aos atos lesivos à Administração Pública. Por esse motivo, deve ser admitida a autocomposição nos processos de improbidade administrativa por diversos fundamentos: a) a possibilidade de colaboração premiada e do acordo de leniência, permitiria a defesa dos mesmos institutos como negócios jurídicos atípicos no processo coletivo (art. 190 do CPC c/c o art. $4^{\circ}$ da Lei 12.850/2013 e com os arts. 16-17 da Lei n. 12.846/2013); b) a negociação prevista nas hipóteses de transação e suspensão condicional do processo, sempre que isso for possível, na respectiva ação penal, observados, por analogia, os limites de negociação ali previstos, também se aplicaria ao processo coletivo de improbidade; c) os acordos parciais, sendo considerados parcela incontroversa o que diz respeito às tutelas não sancionatórias. ${ }^{34}$

Além disso, outro nítido benefício é a desnecessidade de repetição, durante a fase da instrução processual, de prova produzida administrativamente em contraditório no Inquérito

34 DIDIER JR., Fredie; ZANETI JR., Hermes. Justiça Multiportas e Tutela Constitucional Adequada: Autocomposição em Direitos Coletivos. ZANETI JR., Hermes; XAVIER, Tricia Navarro. Justiça Multiportas (Coleção Grandes Temas do Novo CPC). Salvador: JusPodivm, 2016. 
Revista Eletrônica de Direito Processual - REDP.

Rio de Janeiro. Ano 10. Volume 17. Número 2. Julho a Dezembro de 2016

Periódico Semestral da Pós-Graduação Stricto Sensu em Direito Processual da UERJ

Patrono: José Carlos Barbosa Moreira. ISSN 1982-7636. pp. 298-319

www.redp.uerj.br

Civil. Privilegia-se, assim, o princípio da eficiência processual (rectius: efetividade, pois eficiência é um termo da economia e não se confunde com a garantia de efetividade na tutela dos direitos $)^{35}$, previsto no artigo $8^{\circ}$ do $\mathrm{CPC} / 15$, no que diz respeito à redução de custos e a um aumento na celeridade da resolução do conflito por já ter sido produzida prova em contraditório.

Sobre esse enfoque, a ideia de valor probatório relativo das provas produzidas em sede de IC, como defendido nos precedentes do STF e STJ, não deve prosperar. Na análise do conteúdo probatório o juiz poderá dar maior relevância às provas coletadas no IC, quando presente o contraditório. Exemplo disso ocorre no artigo 472 do CPC/15, em que o juiz poderá dispensar a produção de prova pericial quando as partes apresentarem pareceres técnicos ou documento elucidativos, na petição inicial ou contestação. Consequentemente, o dispositivo possibilita que possível parecer técnico produzido em contraditório no IC, não seja reproduzido em juízo.

\section{Conclusões}

Ante todo o exposto, averiguou-se na análise dos precedentes das Cortes Supremas Brasileiras, que estas têm realizado uma interpretação muito restritiva do Inquérito Civil, considerando-o como um instrumento meramente informal e puramente inquisitivo, sem nenhuma exigência ou necessidade da presença do contraditório.

No atual momento vivido pela ordem jurídica brasileira, em que vigora o princípio da jurisdicionalidade e ocorre uma tendente processualização dos procedimentos, todas as atividades estatais devem ser pautadas pela efetiva participação dos cidadãos, como forma de assegurar as garantias fundamentais previstas na Constituição, pois, só assim, os anseios de uma sociedade pautada em um Estado Democrático de Direito serão concretizados pelo ordenamento jurídico.

Assim, é crucial que um contraditório efetivo incida sobre todo andamento do instrumento investigativo do Parquet, devendo sempre adequar-se ao binômio, tutela dos direitos e garantias dos investigados.

\footnotetext{
${ }^{35}$ Ver amplamente: CUNHA, Leonardo Carneiro da. A Previsão do Princípio da Eficiência no Projeto do Novo Código de Processo Civil Brasileiro. In: Revista de Processo, ano 39, v. 233, jul. 2014, p. 65-84.
} 
Revista Eletrônica de Direito Processual - REDP.

Rio de Janeiro. Ano 10. Volume 17. Número 2. Julho a Dezembro de 2016

Periódico Semestral da Pós-Graduação Stricto Sensu em Direito Processual da UERJ

Patrono: José Carlos Barbosa Moreira. ISSN 1982-7636. pp. 298-319 www.redp.uerj.br

Não há oposição, mas sim complementariedade, pelo que se pode formular uma regra pela qual se afirma que haverá tanto contraditório nos inquéritos civis e procedimentos administrativos à cargo do MP quanto seja necessário para reforçar a tutela adequada dos direitos e auxiliar o Parquet na tríplice opção, ajuizar a ação, efetivar um compromisso de ajustamento de conduta ou arquivar o procedimento.

Além disso, com o intuito de preservar os valores da previsibilidade e segurança jurídica, há que se regulamentar de forma pormenorizada o procedimento do IC, como vem fazendo o Ministério Público no âmbito do CNMP (Resolução nº 023/2007 do CNMP) e dos Ministérios Públicos Estaduais (Resolução nº 006/2014, CSMP/MPES). Tais premissas são de extrema importância em sede de IC que apura possíveis fatos decorrentes de atos atentatórios a tutela da probidade administrativa e do patrimônio público, pela própria natureza sancionatória dúplice - reparatória e punitiva - da ação de improbidade, prevista na Lei $\mathrm{n}^{\circ} 8.429 / 92$.

Dessa forma, volta-se a repetir, atribuir conceitos adequados aos institutos jurídicos, diz-se muito sobre sua natureza e possibilita uma melhor compreensão na análise dos mesmos, por isso, o Inquérito Civil deve ser compreendido como o procedimento formal em contraditório, tendencialmente inquisitivo, de que pode se valer exclusivamente o Ministério Público, na coleta de dados e elementos probatórios que possam resultar no exercício de suas funções institucionais para a tutela dos direitos.

\section{REFERÊNCIAS BIBLIOGRÁFICAS}

AARNIO, Aulis. The rational as reasonable. A Treatise on Legal Justification. Dordrecht/Holland: D. Reidel Publishing Company, 1986.

ALEXY, Robert. Teoría de los Derechos Fundamentales. Traducción de Ernerto Garzón Valdés. Madrid: Centro de Estudios Políticos y Constitucionales, 2001.

ANDREWS, Neil. O Moderno Processo Civil. Formas judiciais e alternativas de resolução de conflitos na Inglaterra. Trad.: Teresa Arruda Alvim Wambier. $2^{\mathrm{a}}$ ed. São Paulo: Revista dos Tribunais, 2012.

ABELHA, Marcelo. Ação Civil Pública e Meio Ambiente. São Paulo: Forense Universitária, 2003. 
Revista Eletrônica de Direito Processual - REDP.

Rio de Janeiro. Ano 10. Volume 17. Número 2. Julho a Dezembro de 2016

Periódico Semestral da Pós-Graduação Stricto Sensu em Direito Processual da UERJ

Patrono: José Carlos Barbosa Moreira. ISSN 1982-7636. pp. 298-319 www.redp.uerj.br

CABRAL, Antônio do Passo. As convenções processuais e o termo de ajustamento de conduta. In: ZANETI JR., Hermes. Repercussões do Novo CPC: Processo Coletivo. Salvador. Juspodivm, 2016.

Il principio del contradditorio come diritto d'influeza e dovere di dibattito. In:

Rivista di Diritto Processuale, anno LX, n. 2, aprile-giugno, 2005.

CARVALHO, Ulisses Dias de Carvalho. Uma leitura constitucional do inquérito civil. In: Boletim Científico ESMPU, ano 13, n. 42-43, jan./dez. 2014.

CAVACO, Bruno de Sá Barcelos. O inquérito civil como instrumento efetivo e resolutivo na tutela dos interesses transindividuais - desjudicialização, contraditório e participação. In: Revista de Processo, São Paulo, v. 40, n. 247, set. 2015.

CUNHA, Leonardo Carneiro da. A Previsão do Princípio da Eficiência no Projeto do Novo Código de Processo Civil Brasileiro. In: Revista de Processo, ano 39, v. 233, jul. 2014, p. 65-84.

DANTAS, Miguel Calmon. O Direito Fundamental à Processualização: Fundamento para uma Teoria Geral do Processo. In: DIDIER Jr., Fredie; JORDÃO, Eduardo Ferreira (coord.). Teoria Geral do Processo: panorama doutrinário mundial. Salvador: Juspodivm, 2008.

DIDIER JR., Fredie. Comentários ao artigo $3^{\circ}$ do CPC/15. In: CABRAL, Antônio do Passo; CRAMER, Ronaldo. Comentários ao Novo Código de Processo Civil. São Paulo: Forense, 2015 .

; ZANETI JR., Hermes. Curso de Direito Processual Civil. Processo Coletivo. $10^{a}$ ed. v. 4. Salvador: Juspodivm, 2016.

; ZANETI JR., Hermes. Justiça Multiportas e Tutela Constitucional Adequada: Autocomposição em Direitos Coletivos. ZANETI JR., Hermes; XAVIER, Tricia Navarro. Justiça Multiportas (Coleção Grandes Temas do Novo CPC). Salvador: JusPodivm, 2016. FAZZIO JR., Waldo. Atos de Improbidade Administrativa: doutrina, legislação e jurisprudência. São Paulo: Atlas, 2007.

FIGUEIREDO, Marcelo. Probidade Administrativa. $5^{\text {a }}$ ed. atualizada e ampliada. São Paulo: Malheiros, 2005.

GARCIA, Emerson; ALVES, Rogério Pacheco. Improbidade Administrativa. $6^{\mathrm{a}}$ ed. Rio de Janeiro: Lumen Juris, 2011. 
Revista Eletrônica de Direito Processual - REDP.

Rio de Janeiro. Ano 10. Volume 17. Número 2. Julho a Dezembro de 2016

Periódico Semestral da Pós-Graduação Stricto Sensu em Direito Processual da UERJ

Patrono: José Carlos Barbosa Moreira. ISSN 1982-7636. pp. 298-319

www.redp.uerj.br

GRINOVER, Ada Pellegrini. Inquérito Civil: Contraditório e "Prova Inequívoca" para Fins de Antecipação da Tutela. In: Revista Síntese: Direito Civil e Processual Civil, v. 12, n. 83, maio/jun. 2013.

LOUREIRO, Valtair Lemos. Microssistema processual coletivo e tutela do patrimônio público. Curitiba: Juruá, 2015.

MARINONI, Luiz Guilherme. Precedentes Obrigatórios. 4a ed. São Paulo: Revista dos Tribunais, 2015.

; ARENHART, Sérgio Cruz; MITIDIERO, Daniel. Novo Código de Processo Civil Comentado. São Paulo: Revista dos Tribunais, 2015.

MAZZILI, Hugo Nigro. Inquérito Civil e Poder Investigatório do MP In: MILARÉ, Édis (coord). A Ação Cvil Pública após 20 anos: efetividade e desafios. São Paulo: Revista dos Tribunais, 2005.

MITIDIERO, Daniel. Cortes Superiores e Cortes Supremas. Do Controle à Interpretação, da Jurisprudência ao Precedente. $2^{\mathrm{a}}$ ed. revista, atualizada e ampliada. São Paulo: Revista dos Tribunais, 2015.

. Colaboração no Processo Civil. Pressupostos sociais, lógicos e éticos. $3^{\mathrm{a}} \mathrm{ed}$.

São Paulo: Revista dos Tribunais, 2015.

. Precedentes: da persuasão à vinculação. São Paulo: Revista dos Tribunais, 2016.

NEVES, Daniel Amorim Assumpção. O inquérito civil como uma cautelar preparatória probatória sui generis. In: MAZZEI. Rodrigo; NOLASCO, Rita Dias (coord). Processo Civil Coletivo. São Paulo: Quatier Latin, 2005.

NUNES, Dierle José Coelho. O Princípio do Contraditório: Uma Garantia de Influência e de Não Surpresa. In: DIDIER Jr., Fredie; JORDÃO, Eduardo Ferreira (coord.). Teoria Geral do Processo: panorama doutrinário mundial. Salvador: Juspodivm, 2008.

OTERO, Paulo. Legalidade e administração pública: o sentido da vinculação administrativa à juridicidade. Lisboa: Almedina, 2003.

PECZENIK, Aleksander. On Law and Reason. Netherlands: Springer, 2009.

QUEIROZ, Ronaldo Pinheiro de. A eficácia probatória do inquérito civil no processo judicial de combate à corrupção. In: SALGADO, Daniel de Resende; QUEIROZ, Ronaldo Pinheiro de. A Prova no Enfrentamento à Macrocriminalidade. Salvador: Juspodivm, 2015. 
Revista Eletrônica de Direito Processual - REDP.

Rio de Janeiro. Ano 10. Volume 17. Número 2. Julho a Dezembro de 2016

Periódico Semestral da Pós-Graduação Stricto Sensu em Direito Processual da UERJ

Patrono: José Carlos Barbosa Moreira. ISSN 1982-7636. pp. 298-319

www.redp.uerj.br

SARLET, Ingo Wolfgang. A eficácia dos direitos fundamentais. $4^{\mathrm{a}}$ ed. Porto Alegre: Livraria do Advogado, 2004.

TARUFFO, Michele. Il Vertice Ambiguo: Saggi sulla Cassazione Civile. Bolgna: Il Mulino, 1991.

Precedente e giurisprudenza. Napoli: Editoriale Scientifica, 2007.

TESHEINER, José Maria; PEZZE, Sabrina. Inquérito Civil e Termo de Ajustamento de Conduta. In: Revista de Direito Administrativo, Rio de Janeiro, v. 263, mai/ago. 2013.

ZANETI JR., Hermes. A Constitucionalização do Processo. O modelo constitucional da justiça brasileira e as relações entre processo e Constituição. $2^{\mathrm{a}}$ ed. São Paulo: Atlas, 2014. . O valor vinculante dos precedentes: teoria dos precedentes normativos formalmente vinculantes [2015]. $2^{\mathrm{a}}$ ed., revista e atualizada. Salvador: JusPodivm, 2016. . Comentários ao artigo 926 do CPC/15. In: CABRAL, Antônio do Passo; CRAMER, Ronaldo. Comentários ao Novo Código de Processo Civil. São Paulo: Forense, 2015.

. Comentários aos artigos 176 a 181 do CPC/15. In: STRECK, Lênio; NUNES, Dierle; CUNHA, Leonardo Carneiro da. Comentários ao Código de Processo Civil. São Paulo: Saraiva, 2016.

- A Legalidade na era das Necessidades de Tutela: Princípio da Constitucionalidade e Legalidade Ampla. In: Normas Fundamentais (Coleção Grandes Temas do Novo CPC). Salvador: Juspodivm, 2016. 